\title{
Online-Based Nutrition Education to Reduce Sugar, Salt, and Fat Intake in School Children: A Research Protocol
}

\author{
Trias Mahmudiono ${ }^{1 *}$, Rahayu Indriasari ${ }^{2}$, Dina Rahayuning Pangestuti ${ }^{3}$, Qonita Rachmah ${ }^{1}$, Septa Indra Puspikawati ${ }^{1}$ \\ Fatqiatul Wulandari ${ }^{1}$, Susi Hidayah ${ }^{1}$ \\ ${ }^{1}$ Department of Nutrition, Faculty of Public Health, Universitas Airlangga, Surabaya, Indonesia; ${ }^{2}$ Department of Nutrition, \\ Faculty of Health, Universitas Hassanudin, Makassar, Indonesia; ${ }^{3}$ Department of Public Health Nutrition, Faculty of Public \\ Health, Universitas Diponegoro, Semarang, Indonesia
}

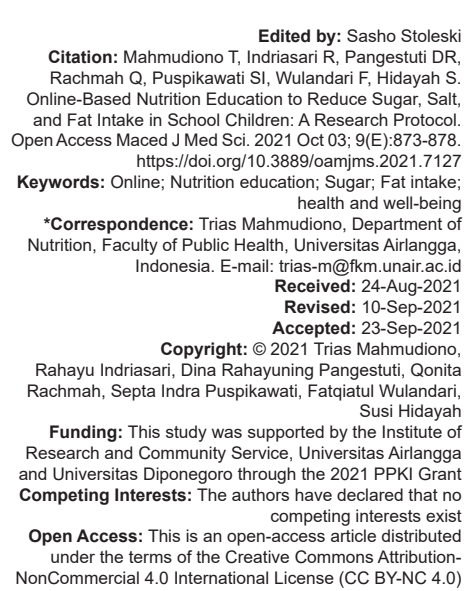

\begin{abstract}
BACKGROUND: Indonesia is currently facing a very complex health problem. Non-communicable diseases (NCDs), for instance, are not only suffered by adolescence or adults, but nowadays, children are also facing the same problem. In children, obesity can be a dangerous risk factor for NCDs later in life. In 2013, the prevalence of overweight and obese children aged 5-12 years in Indonesia reached 18.8\%. Meanwhile, in the industrial era 4.0 , the development of technology and information is running very rapidly and may affect on food preferences of children, especially sugar, salt, and fat intake on children. Hence, schools play an important role in helping students establish healthy eating behaviors.

AIM: Since nutrition was not a curriculum in elementary school Indonesia and studies related to nutrition education with the intensive methods through online platforms are still limited, this study aims to explore the effectiveness of 8-week nutrition education related to improving knowledge, attitude, practice, subjective norms, and perceived behavior control of children toward limiting sugar, salt, and fat intake on children aged 8-12 years.

METHODS: This is a randomized control trial study by giving nutrition education intervention related to sugar, salt, and fat consumption to schoolchildren. This study targets elementary schoolchildren using a quasi-experiment design with a pre-post test control group design. The study will be conducted online in 3 urban areas (center) in Indonesia, namely: Surabaya, Semarang, and Makassar City. There are 13 elementary schools involved, consisting of 5 schools from Surabaya City, 4 from Semarang City, and 4 from Makassar City. A total of 300 elementary school students aged 8-12 years as well as 26 teachers are joining in this research. This study has the number: U11111268-9302 for the Universal Trial Number and approved by Thai Clinical Trial Registry (TCTR) with identification number: TCTR20210824013.
\end{abstract}

\section{Introduction}

\section{Background}

Indonesia is currently facing a very complex health problem. Non-communicable diseases (NCDs) are rapidly increased, while infectious diseases are still quite dominant. NCDs, for instance, are not only suffered by adolescence or adults, but nowadays, children are also facing the same problem. In children, obesity can be a dangerous risk factor for NCDs, such as hypertension, cardiovascular disease, and diabetes mellitus later in life [1]. In 2013, the prevalence of overweight and obese children aged 5-12 years in Indonesia reached $18.8 \%$ (10\% for overweight and $8.8 \%$ for obese children). This number was increased from 2012 where the prevalence of overweight children was $9.2 \%$ [2].

In general, obesity is caused by an imbalance between energy intake and energy expenditure. Exceeding energy expenditure through energy intake may lead to excessive weight gain in obese children. Thus, the quality of the diet is important for maintaining the body weight [3]. In terms of diet, the consumption of sugar, salt, and fat are also important to be considered in our daily intake. Documented evidence showed that there were associations between excessive dietary sugars, salt, and fat and increased risk of NCDs, including obesity [4]. On the other hand, the promotion of potentially unhealthy food and beverage products is now widely recognized as a significant risk factor for child obesity and for the development of diet-related NCDs through rapidly expanding media (digital television, online marketing, mobile, and smartphones) [5].

In the industrial era 4.0, the development of technology and information is running very rapidly and may affect on food selection (food preferences) of children. Food delivery online platforms are also widely spread and easily accessible by everyone. However, most of the food bought by the online platform is fast food (junk food), which contains high sugar, salt, and fat [6]. To encourage the reduction of salt consumption, 
a country that successfully intervened in nutrition education with School-EduSalt, for example, is China. School-EduSalt interventions in this country have successfully decreased salt intake $(1.9 \mathrm{~g} / \mathrm{d}$ in children and $2.9 \mathrm{~g} / \mathrm{d}$ in adults), as well as systolic blood pressure (2.3 $\mathrm{mmHg}$ in adults) [7].

Schools play an important role in helping students establish healthy eating behaviors. Nutrition education is a vital part of a comprehensive health education program and empowers children with knowledge and skills to make healthy food and beverage choices [8]. Since nutrition was not a curriculum in elementary school Indonesia and studies related to nutrition education with intensive methods using the online platforms are still limited, this study aims to explore the effectiveness of 8-week nutrition education related to improving knowledge, attitude, practice, subjective norms, and perceive behavior control of children toward limiting sugar, salt, and fat intake on children aged 8-12 years and their nutritional status. In this study, we also encourage teachers to provide nutrition education for students through the "Nutrition Education Competition for Elementary School Teachers" conducted by the researcher. This study will be conducted online due to the COVID-19 pandemic situation. Furthermore, this study is expected to be a starting point to make nutrition education one of the teaching materials or compulsory subjectS for elementary schools in Indonesia.

The benefits of nutrition on growing school kids cannot be overemphasized, as it plays a significant role in improving the health of the students. Every school should have a nutrition program where students are taught extensively on nutrition and are given foods based on nutritional standards. With an improved knowledge of nutrition and consistently making healthier meal choices, students are likely to have improved academic performance [9]. Ensuring that children get the food education that they need, can give them the knowledge and skills to be in charge of making healthier decisions in the future.

\section{Study objective}

The aims of the study are to determine the effectiveness of 2 months ( 8 meetings) online-based nutrition education related to reduction on sugar, salt, dan fat consumption as well as nutritional status in reducing the risk factor of obesity on elementary school students aged 8-12 years in 3 centers (Surabaya, Semarang, and Makassar City) compared to the control group.

The primary objective is to determine the effectiveness of 2 months (8 meetings) online-based nutrition education related to reduction on sugar, salt, and fat consumption versus control group on students' nutritional status in 3 centers (Surabaya, Semarang, and Makassar City).

\section{Primary hypothesis}

Online-based nutrition education for 2 months associated with the restriction on sugar, salt, and fat consumption and nutritional status of elementary school students compared to the control group.

\section{Secondary objective}

\section{Students' nutrition knowledge and attitude}

1. Determine elementary school students' nutrition knowledge related to restriction on sugar, salt, and fat consumption compared to control group during 2 months (8 meetings) of education

2. Determine elementary school students' attitude toward sugar, salt, and fat consumption during 2 months (8 meetings) of education

3. Determine the physical activity and intake changes on elementary school students during the COVID-19 pandemic.

\section{Students' weight changes}

1. Measure mean weight change (total change), comparing both intervention groups separately to control group through self-reported, measured before and after education

2. Determine student's consumption related to sugar, salt, and fat intake through Frequency Food Questionnaire, comparing both intervention and control groups, before and after education.

Teacher's role during "Nutrition Education Competition for Elementary School Teacher"

1. Determine elementary school teacher's efficacy task and barrier on giving nutrition education for the student during 2 months of education

2. Determine teacher's nutrition knowledge during 2 months of education.

\section{Methods}

\section{Study design}

This is a randomized control trial study by giving nutrition education intervention related to sugar, salt, and fat consumption to schoolchildren. This study targets elementary schoolchildren using a quasiexperiment design with a pre-post test control group design. The experimental design aims to determine the effectiveness of nutrition education interventions through an online platform for schoolchildren. Respondents will be divided into two groups, intervention (treatment) group control group. 


\section{Participant selection and enrolement}

\section{Identifying and selecting participant}

Subjects are part of a population that can be determined in a number using certain means and existing considerations. One way to calculate the number of subjects was to use the Slovin formula (1960), as follows:

$$
\begin{gathered}
n=\frac{N}{1+\mathrm{Ne}^{2}} \\
n=\frac{132}{1+\left[132 \times\left(0.05^{2}\right)\right]} \\
n=\frac{132}{1+132 \times(0.0025)} \\
n=\frac{132}{1.33}
\end{gathered}
$$

$\mathrm{n} \quad=99.24 \approx 100$ children

$\mathrm{n} \quad=$ sample size

$\mathrm{N} \quad=$ population size

e $\quad=$ Fault tolerance limit (0.005)

Based on the calculations using the Slovin formula, each center (city) obtained a minimum sample needed as many as 100 elementary school children who were divided randomly for the control group (50 students) and intervention group (50 students). So, as for 3 centers (Surabaya, Semarang, and Makassar City), the total sample needed is as many as 300 elementary schoolchildren aged 8-12 years. Children will be recruited from teachers who join the "Nutrition Education Competition for Elementary School Teachers." The teachers will send the name, phone number, and any other identity to the researcher for follow-up. Recruitment, random allocation, and intervention are illustrated using the Consort diagram in Figure 1.

\section{Consenting participant}

Guardians of the participants will be informed about the purpose of the study, the procedures involved when participating, and asked for their consent. The parent or guardian of the child must be older than 18 years of age to give consent. Informed consent will be in Indonesian and it also explains briefly about the study, purpose, duration, as well as rights and obligations of respondents. It will be explained to the guardian or parents that participation is voluntary and the respondent will be educated particularly by Nutrition Educator from the researcher. Participants will receive informed consent through their teacher.

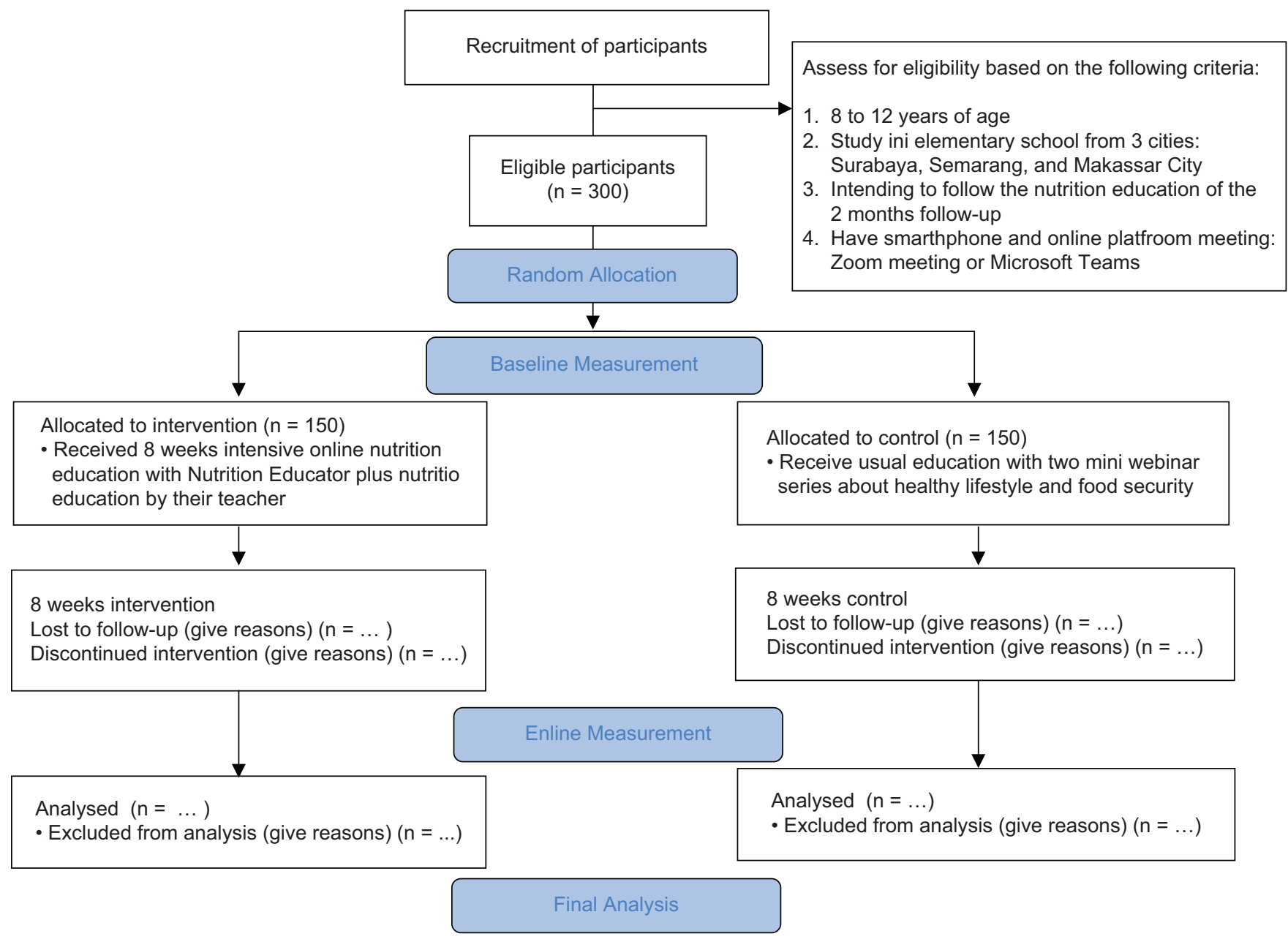

Figure 1: The CONSORT diagram of the study [10] 


\section{Recruitment of participants}

Due to the COVID-19 pandemic situation, offline recruitment is not possible, so it must be carried out online. The research team conducted several promotions with social media and contacted schools directly in three cities through the "Nutrition Education Competition for Elementary School Teacher" strategy. Through this competition, it is expected that the aspirations, creativity, and innovation of elementary school teachers in delivering nutrition and health education materials to students can be delivered properly. The big theme of this competition is "Online-Based Nutrition Education to Reduce Sugar, Salt, and Fat Intake in School Children." In addition, through this competition, teachers are required to send participants for our research, to be composed of students in grades 4-6 elementary school.

The purpose of the "Nutrition Education Competition for Elementary School Teacher" is as follows:

1. Increase the active role of elementary school teachers in educating students to reduce sugar, salt, and fat intake

2. Accommodate the creative ideas of elementary school teachers to convey health education materials related to sugar, salt, and fat intake to students

3. Facilitate teachers in delivering health education materials related to sugar, salt, and fat intake to learners

4. Support the role of teachers as a character shaper of students who care about nutrition and health

5. Recruit competent students to join our research.

The requirements of the "Nutrition Education Competition for Elementary School Teacher" are as follows:

1. Indonesian Citizen

2. Recorded as an active teacher of an elementary school in 2021

3. Teachers who are registered in this competition may come from the same school (one school is allowed to send one or more teachers)

4. Teachers are required to make proposals (educational plans) themed "Online-Based Nutrition Education to Reduce Sugar, Salt, and Fat Intake in School Children" and designed to be conducted as many as 8 meetings ( 2 months education)

5. The proposal has never been contested/ submitted to any competition.

\section{Randomisation}

Simple randomization will be implemented. There will be no reference to assigned study groups (e.g. no use of terminologies such as group $A, B$, or
C). Rather, the total patient numbers will be randomly allocated to an equal proportion of one of the three groups. The randomization list will be computer generated by a statistician. Details of the recruitment, random allocation and intervention of the study was further depicted align with the consort diagram [10].

\section{Study site}

\section{Setting and number of participants}

The study will be conducted online through Zoom Meeting/Microsoft Teams in 3 urban areas (center) in Indonesia, namely: Surabaya, Semarang, and Makassar City. We will conduct a "Nutrition Education Competition for Elementary School Teachers" in these 3 cities as a means to recruit students to participate in this study. There are 13 elementary schools involved, consisting of 5 schools from Surabaya City, 4 from Semarang City, and 4 from Makassar City. A total of 300 elementary school students aged 8-12 years as well as 26 teachers are joining in this research.

\section{Inclusion criteria}

Children will be included if they meet all the following inclusion criteria:

1. 8-12 years of age

2. Study ini elementary school from 3 cities: Surabaya, Semarang, and Makassar City

3. Intending to follow the nutrition education of the 2 months follow-up

4. Have smartphone and online platform meeting: Zoom meeting or Microsoft Teams.

\section{Exclusion criteria}

Children who follow a specific or special diet as stated by parents or clinicians will not be included in this study.

\section{Data collection and statistical analysis}

Data will be collected through a pre-post test questionnaire and given to all participants (both for intervention and control group) online. All available data will be analyzed descriptively. Results will be summarized as frequencies and percentages for nominal data. Bivariate analysis was done using the Chi-square test with a nominal data scale. Results for bivariate analysis will be summarized as p-value and cross-tabulation table. Meanwhile, multivariate analysis was performed using logistic regression tests to determine which variable was the most dominant in influencing dependent variables. The results from the multivariate analysis will be summarized as p-value, odds ratio, and 95\%-confidence interval. The normality test was analyzed using the Kolmogorov-Smirnov test. To analyze the effectiveness of online nutrition education, the ANOVA 
test will be conducted. All the statistical analyses before will be performed using IBM SPSS 25 software.

\section{Intervention}

\section{Intervention allocation}

Twenty-four trained Nutrition Educators from various universities in Indonesia are hired to deliver the intervention on a weekly basis. As for further steps, participants will be contacted by the researcher to join into Whatsapp Group with Nutrition Educator. Students for intervention will be divided into 10 groups in each center, consisting of 5 students in each group who will get nutrition education related to sugar, salt, and fat consumption intensively with a Nutrition Educator for 2 months ( 8 meetings/once a week). For the rest 50 students as control, the researcher will give them education, twice, with different topics. The duration for each meeting is around 30-60 min. In each group, the researcher will contact the participant for further schedule and Zoom Meeting/Teams' link, as well as coordinate participants to join the education each week.

\section{Intervention group}

In the intervention group, participants will get the nutrition education materials from Nutrition Educator with different aspects each week. Baseline and endline for the control group will be conducted in weeks 0 and 9 . The curriculum for the intervention group is stated in Table 1.

Table 1: Intervention group's schedule and activity

\begin{tabular}{|c|c|c|}
\hline Week & Variable-related study & Activity \\
\hline 0 & Baseline & $\begin{array}{l}\text { - Participants are asked to fill in the online } \\
\text { questionnare }\end{array}$ \\
\hline 1 & $\begin{array}{l}\text { Children's characteristics } \\
\text { and social media usage }\end{array}$ & $\begin{array}{l}\text { - Dynamic group } \\
\text { - Online challenges delivery through social media } \\
\text { for week } 3\end{array}$ \\
\hline 2 & $\begin{array}{l}\text { Children's subjective } \\
\text { norms }\end{array}$ & $\begin{array}{l}\text { - Mini games with PowerPoint related to social } \\
\text { media usage and food preferences } \\
\text { - Children are asked to tell their favorite social } \\
\text { media and the reason }\end{array}$ \\
\hline 3 & $\begin{array}{l}\text { Level of nutritional's } \\
\text { knowledge }\end{array}$ & $\begin{array}{l}\text { - Open card game with nutrition material: } \\
\text { - Sugar, salt, and fat overview } \\
\text { - Sugar, salt, and fat's benefit for children's health } \\
\text { - Type of food and intake recommendation } \\
\text { - Sugar, salt, and fat-high food photo challenge } \\
\text { with creative caption }\end{array}$ \\
\hline 4 & $\begin{array}{l}\text { Children's attitude toward } \\
\text { sugar, salt, and fat-high } \\
\text { food }\end{array}$ & $\begin{array}{l}\text { - Experiences in sugar, salt, and fat-high food } \\
\text { intake with storytelling } \\
\text { - Nutrition Educator tell the participants that there will } \\
\text { be a "Mini Story Telling Contest" for children in week } 7\end{array}$ \\
\hline 5 & $\begin{array}{l}\text { Role model for sugar, salt, } \\
\text { and fat intake on children }\end{array}$ & $\begin{array}{l}\text { - Nutrition Educator are asked to show pictures } \\
\text { related to sugar, salt, and fat-high food to } \\
\text { participants } \\
\text { - Children are asked to tell who is their role model } \\
\text { in sugar, salt, and fat intake }\end{array}$ \\
\hline 6 & $\begin{array}{l}\text { Children's pratice in } \\
\text { reducing sugar, salt, and } \\
\text { fat-high food intake }\end{array}$ & $\begin{array}{l}\text { - Mini-games with Kahoot.it about sugar, salt, and } \\
\text { fat-high favorite food } \\
\text { - Nutrition Educator are asked to interpret } \\
\text { Nutrition Fact }\end{array}$ \\
\hline 7 & $\begin{array}{l}\text { Children's attitude toward } \\
\text { sugar, salt, and fat-high } \\
\text { food }\end{array}$ & $\begin{array}{l}\text { - "Mini Story Telling Contest" for participants } \\
\text { - Feedback from Nutrition Educator }\end{array}$ \\
\hline 8 & $\begin{array}{l}\text { Evaluation and } \\
\text { testimonials }\end{array}$ & $\begin{array}{l}\text { - Participants are asked to tell their experience } \\
\text { and impression during the study }\end{array}$ \\
\hline 9 & Endline & $\begin{array}{l}\text { - Participants are asked to fill in the online } \\
\text { questionnare }\end{array}$ \\
\hline
\end{tabular}

\section{Control group}

In the control group, participants will get the nutrition education materials from the researcher in 2 meetings ( 2 weeks of intervention). Baseline and endline for the control group will be conducted in weeks 0 and 2 . The curriculum for the control group is stated in Table 2.

All groups will be given the written material through the Center for Health and Nutrition Education,Counseling and Empowerment (CHeNECE) Research Group's website, and can be accessed from https://chenece-fkmunair.com/.

Table 2: Control group's schedule and activity

\begin{tabular}{|c|c|c|}
\hline Week & Variable-related study & Nutrition education theme \\
\hline 0 & Baseline & $\begin{array}{l}\text { Participants are asked to fill in the } \\
\text { online questionnaire }\end{array}$ \\
\hline 1 & $\begin{array}{l}\text { Children's characteristics, practice, } \\
\text { attitude, level of nutritional's knowledge } \\
\text { related to sugar, salt, and fat intake }\end{array}$ & $\begin{array}{l}\text { Mini webinar series } 1 \text { : Healthy } \\
\text { lifestyle behavior on children }\end{array}$ \\
\hline 2 & $\begin{array}{l}\text { Children's characteristics, practice, } \\
\text { attitude, level of nutritional's knowledge } \\
\text { related to sugar, salt, and fat intake }\end{array}$ & Mini webinar series 2: Food Security \\
\hline 3 & Endline & $\begin{array}{l}\text { Participants are asked to fill in the } \\
\text { online questionnare }\end{array}$ \\
\hline
\end{tabular}

\section{Feasibility}

\section{Study investigator and their roles}

This study is a collaboration research between 3 universities in Indonesia: Universitas Airlangga in Surabaya City, Universitas Diponegoro in Semarang City, and Universitas Hasanuddin in Makassar City. Each university has the responsibility to maintaining each center's intervention study since we have 3 different locations for nutrition education. An advisory committee will advise the PI at crucial stages on the design and implementation of the study. Details of the role and responsibilities of each researcher are found in Table 3.

\section{Study funding}

This study is funded by the Institute of Research and Community Service in Universitas Airlangga and Universitas Diponegoro.

\section{Study Organisation}

\section{Coordination}

A field research coordinator will be dedicated to ongoing supervision and monitoring of study implementation. Data collection will be monitored and evaluated regularly by the statistician. Principle investigator along with the field coordinator will also communicate regularly with the co-investigator to make sure the implementation is going well. 
Table 3: Study investigation and their roles

\begin{tabular}{|c|c|c|c|}
\hline Name & Title & Role & Affiliation \\
\hline $\begin{array}{l}\text { Mahmudiono, } \\
\text { Trias }\end{array}$ & $\begin{array}{l}\text { Principle } \\
\text { investigator }\end{array}$ & $\begin{array}{l}\text { Responsible for } \\
\text { conceptualization, data } \\
\text { curation, investigate } \\
\text { implementation for all } \\
\text { centre, methodology, } \\
\text { funding acquisition, } \\
\text { resource, validation, } \\
\text { visualitatin, supervision, } \\
\text { writing-review, and } \\
\text { editing }\end{array}$ & $\begin{array}{l}\text { Department of Nutrition, } \\
\text { Faculty of Public Health, } \\
\text { Universitas Airlangga }\end{array}$ \\
\hline $\begin{array}{l}\text { Indriasari, } \\
\text { Rahayu }\end{array}$ & Co-investogator & $\begin{array}{l}\text { Responsible for data } \\
\text { curation, investigate } \\
\text { implementation in } \\
\text { Makassar City center, } \\
\text { validation, visualitatin, } \\
\text { supervision, } \\
\text { writing-review, and } \\
\text { editing }\end{array}$ & $\begin{array}{l}\text { Department of Nutritional } \\
\text { Science, Faculty of } \\
\text { Public Health, Universitas } \\
\text { Hassanudin }\end{array}$ \\
\hline $\begin{array}{l}\text { Pangestuti, } \\
\text { Dina } \\
\text { Rahayuning }\end{array}$ & Co-investogator & $\begin{array}{l}\text { Responsible for data } \\
\text { curation, investigate } \\
\text { implementation in } \\
\text { Semarang City center, } \\
\text { validation, visualitatin, } \\
\text { supervision, } \\
\text { writing-review, and } \\
\text { editing }\end{array}$ & $\begin{array}{l}\text { Department of Public } \\
\text { Health Nutrition, Faculty of } \\
\text { Public Health, Universitas } \\
\text { Diponegoro }\end{array}$ \\
\hline $\begin{array}{l}\text { Wulandari, } \\
\text { Fatqiatul }\end{array}$ & $\begin{array}{l}\text { Field Research } \\
\text { Coordinator }\end{array}$ & $\begin{array}{l}\text { Responsible for hiring } \\
\text { and training of Nutrition } \\
\text { Educator, organize } \\
\text { implementation, } \\
\text { procedure, follow-up } \\
\text { education, and daOta } \\
\text { entry }\end{array}$ & $\begin{array}{l}\text { Department of Nutrition, } \\
\text { Faculty of Public Health, } \\
\text { Universitas Airlangga }\end{array}$ \\
\hline Hidayah, Susi & $\begin{array}{l}\text { Statistician and } \\
\text { Administrator }\end{array}$ & $\begin{array}{l}\text { Responsible for } \\
\text { sampling and statistical } \\
\text { procedures, analysis, } \\
\text { interpretation of } \\
\text { results, data collection, } \\
\text { administration process, } \\
\text { and formulation of } \\
\text { recommendation }\end{array}$ & $\begin{array}{l}\text { Department of Nutrition, } \\
\text { Faculty of Public Health, } \\
\text { Universitas Airlangga }\end{array}$ \\
\hline
\end{tabular}

\section{Staff, training, and supervision}

In this study, we recruit Nutrition Educator to give the education material for elementary school students. Nutrition Educators will be trained regularly, once a week (a total of 8 meetings for training), before they educate the students. A field coordinator will also evaluate and control the performance of the Nutrition Educator during 2 months of implementation.

\section{Ethical consideration}

The study will be performed in accordance with ethical principles that have their origin in the World Health Organization-Council for International Organizations of Medical Sciences. This study has already been considered by the Health Research Ethics Committee, Universitas Airlangga, School of Medicine, Surabaya, Indonesia No.898/EC/KEPK/FKUA/2021. The Universal Trial Number for this study is U11111268-9302. This study has registered at the Thai Clinical Trials Registry and has still waiting for the registered number. Participants are recruited through the "Nutrition Education Competition for Elementary School Teacher" and given verbal and written information about this research. Furthermore, participants are given verbal and written informed consent by the teacher to fulfill the requirement. Participants may withdraw from this study anytime without negative consequences.

\section{Acknowledgment}

This research protocol is based on the study from the 2021 Indonesian Collaboration Research Program conducted by researchers from Universitas Airlangga, Universitas Diponegoro, and Universitas Hasanuddin. The authors are thanking all the teachers and students involved in this study in 3 cities (Surabaya, Semarang, and Makassar City).

\section{References}

1. UNICEF Indonesia. Indonesia: Obesity Rates Among Adults Double Over Past Two Decades. Indonesia: UNICEF IndonesiaPress Release; 2021. Available from: https://www.unicef.org/ indonesia/press-releases/indonesia-obesity-rates-among-adultsdouble-over-past-two-decades. [Last accessed on 2021 Aug 23].

2. The Ministry of Health. Basic Health Research Report 2013. Jakarta: The Ministry of Health; 2013. Available from: https:// www.litbang.kemkes.go.id/laporan-riset-kesehatan-dasarriskesdas. [Last accessed on 2021 Aug 23].

3. Romieu I, Dossus L, Barquera S, Blottière HM, Franks PW, Gunter M, et al. Energy balance and obesity: What are the main drivers? Cancer Causes Control. 2017;28(3):247-58. https://doi. org/10.1007/s10552-017-0869-z

PMid:28210884

4. Pervin R, Hossain MA, Debnath D, Nath BD. Epidemiological perspectives of dietary sugars, salts and fats. Diet Sugar Salt Fat Hum Heal. 2020;2020:3-23.

5. World Health Organization. Marketing of Foods High in Fat, Salt and Sugar to Children: Update 2012-2013. Europe: World Health Organization; 2013. Available from: https://www.euro. who.int/_data/assets/pdf_file/0019/191125/e96859.pdf. [Last accessed on 2021 Aug 23].

6. Indrayana S, Palupi NS. Strategi implementasi pencantuman informasi kandungan gula, garam, dan lemak untuk pencegahan risiko penyakit Tidak Menular. Mutu Pangan. 2014;1(2):156-64.

7. He FJ, Wu Y, Feng XX, Ma J, Ma Y, Wang H, et al. School based education programme to reduce salt intake in children and their families (School-EduSalt): Cluster randomised controlled trial. BMJ. 2015;350(13):h770. https://doi.org/10.1136/bmjopen-2013-003388 PMid:23864214

8. Centers for Disease Control and Prevention. Nutrition Education in US Schools; 2021. Available from: https://www.cdc.gov/ healthyschools/nutrition/school_nutrition_education.htm. [Last accessed on 2021 Aug 22].

9. The Importance of Nutritional Education in Schools; 2020 Available from: https://www.world.edu/the-importance-ofnutritional-education-in-schools. [Last accessed on 2021 Aug 23].

10. Consort. The Consort Diagram; 2010. Available from: http:// www.consort-statement.org/consort-statement/flow-diagram. [Last accessed on 2021 Aug 23]. 